\title{
РАЗВИТИЕ КОРПОРАТИВНОЙ СОЦИАЛЬНОЙ ОТВЕТСТВЕННОСТИ ПОД ВЛИЯНИЕМ НАЦИОНАЛЬНОЙ КУЛЬТУРЫ СТРАНЫ
}

\author{
(c) 2018 Волнухин Константин Васильевич \\ аспирант \\ Российская академия народного хозяйства и государственной службы \\ при Президенте Российской Федерации (РАНХиГС) \\ 119571, Москва, проспект Вернадского, 82 \\ E-mail: lisenok100@gmail.com
}

В современном мире все большую роль в правилах ведения бизнеса занимает корпоративная социальная ответственность. Соблюдение предъявляемых обществом и государством требований способствует повышению конкурентоспособности компании. Бизнес развивает КСО, опираясь на национальные особенности и перенимая лучший опыт других стран.

Ключевые слова: корпоративная социальная ответственность, национальные модели КСО, корпоративная культура, ответственный бизнес.

Последнее время заметно размытие границ в правилах формирования и развития социальной ответственности бизнеса, национальные модели разных стран перенимают лучший опыт, компании в попытке стать более эффективными и качественными для клиентов стремятся быть на острие современных технологий и бизнес-процессов. Более того, с развитием самих стран все более существенное внимание уделяется человеку, сотруднику, теперь он не один из механизмов, а основа всего, это наиболее ценный актив компании. В тренде корпоративная социокультура с повышенным вниманием к самореализации и творчеству сотрудника вкупе с созданием всех необходимых для этого условий.

Поэтому необходимо осветить понятие корпоративной социальной ответственности (КСО). Виды КСО в странах развиваются под влиянием специфики национальной культуры. Основная разница в этих подходах следующая: либо бизнес сам определяет рамки своей ответственности перед обществом, либо на бизнес влияют институты государства и предъявляют социальные требования. Поэтому выделяют «открытый» и «скрытый» подходы.

США является ярким примером «открытого» подходы, компании сами определяют границы своей ответственности и осуществляют активность. Однако, как и в случае с корпоративной культурой происходят определенные трансформации, общество требует от бизнеса большей прозрачности, внутреннего контроля и социальной ответственности. В связи с этим в
2002 г. был даже принят закон Сарбейнса-Оксли, что стало одним из самых существенных изменений американского законодательства в области ценных бумаг. Он подразумевал ужесточение требований к подготовке и самой финансовой отчетности на фоне распространения злоупотреблений менеджеров крупных корпораций и разрастающихся корпоративных скандалов.

В Канаде действует похожий на американский подход с поправкой на то, что бизнес взаимодействует с Национальным Институтом Качества Канады, внедряющим в них государственный стандарты КСО, ориентированных на повышение качества и улучшение условий труда. Этот государственный институт продвигает необходимость соблюдать нормы КСО национальным компаниям и за рубежом, соответствуя всем местным законам, но сохраняя национальные особенности и ценности.

Корпоративная социальная ответственность в Канаде совершенствовалась от фокуса на хороших условиях труда к роли частных компаний как участников международных отношений и воздействующих на общество в целом.

Континентальная Европа отличается противоположным подходом, здесь все нормы изначально транслируются государством. И если для США некоторые активности в области КСО всегда были на добровольной основе, то в Европе они регулируются законами, нормами и стандартами.

В этой связи английский подход является 
компромиссным. Здесь активны как гражданские институты и государство в части выдвижения общественных интересов, так и бизнес в области применения лучших практик, ведь они поощряются государством. В целом в Великобритании как и в Европе традиционно сильная поддержка бизнеса.

Поддержка проявляется в налоговых льготах для организаций, которые ведут социально ориентированную политику с учетом деловой этики. Также приветствуется публичное освещение своих подходов к социальной сфере и работе с персоналом.

Новым трендом европейской модели КСО является постепенный переход от скрытой к открытой своей формы как в США, побуждаемый все большей активностью и инициативностью компаний. Если западный образец подхода к КСО выражается в стремлении компании увеличить прибыли и использовать, в том числе свои достоинства в области КСО перед конкурентами, то в восточном аналоге акцент сделан на коллективизм и значение человека в коллективе. Все особенности корпоративной культуры Востока в равной степени справедливы и в подходе к КСО.

Многие эксперты сходятся во мнении, что вскоре подход к управлению банками соединит в себе западное стремление к успеху и прибылям и восточное - к внутренней гармонии.

Восточная модель проповедует моральное поведение, этику корпоративного управления, отношение сотрудников к вопросам этики. Моральные принципы берутся за основу становление корпоративной культуры. Некоторые профессионалы в области КСО утверждают, что на Западе волна активности к этой области связана именно с изначальным восточным подходом к менеджменту, основанным на моральных и этических принципах.

КСО в Японии предполагает социальную сплоченность на уровне компании и деловую сплоченность на уровне подразделения. Велика роль государства в планировании подходов корпоративных стратегий компаний. Бизнес не стремится к получению сверхприбылей, гораздо важнее осознание ответственности перед обществом и стремление к прогрессу. Топ-ме- неджеры и собственники компаний традиционно выстраивают тесные отношения со властью и собственным персоналом.

Китайский подход к КСО на сегодняшний день ориентирован на развитие социальных услуг, рост налоговых отчислений и рост количества и качества рабочих мест, стремлении принести общественную пользу. Еще один принципиальный момент это тесная связка развития компании и сотрудника в нем. То есть сама концепция развития банка строится на развитии персонала.

Существует и исламский подход к КСО, который основывается на моральных и этических нормах в рамках религии, без отрыва от нее. Часто со стороны исламский экспертов можно слышать упреки в адрес западных моделей КСО. Они заключаются в том, что на западе компании хотят быть «хорошими» и получать за это дополнительные выгоды (налоговые льготы, преференции в выборе компании). Однако, бизнес изначально должен таким быть. Конечно, исламская модель не игнорирует необходимость получения прибыли, но прибыль, по их мнению, это естественный элемент, без него и предпринимательской деятельности существовать не может.

Резюмируя, исламский подход к КСО призывает собственников бизнеса стремиться получить нематериальное счастье в этой и будущей жизни, а этого можно добиться, трепетно относясь к социальной ответственности и в стремлении к общему благополучию (ответственность за это благополучие других).

Сравнение основных подходов в системах КСО разных стран представлено в таблице.

Корпоративная социальная ответственность за рубежом это не просто актуальный тренд в привлекательном для общества виде, это действительно серьезный приоритет при ведении бизнеса, соблюдение всех норм и ценностей, а также внедрение новых подходов и лучших практик поощряется со стороны государства и привлекает новых инвесторов. Более того многие обеспеченные слои населения, как потенциальные клиенты, делают свой выбор, в том числе обращая внимание на политику компании в области КСО. 
Таблица. Сравнение подходов в моделях КСО в культурах стран мира

\begin{tabular}{|c|c|c|c|c|}
\hline Модели КСО & $\begin{array}{c}\text { Американская } \\
\text { (канадская) }\end{array}$ & $\begin{array}{c}\text { Континентальная } \\
\text { (европейская) }\end{array}$ & $\begin{array}{c}\text { Японская } \\
\text { (китайская) }\end{array}$ & Исламская \\
\hline Форма КСО & Открытая & Скрытая & Скрытая & Скрытая \\
\hline $\begin{array}{c}\text { Экономическая } \\
\text { ответственность }\end{array}$ & $\begin{array}{c}\text { Внедрение лучших } \\
\text { опытов корпоратив- } \\
\text { ного управления, } \\
\text { проработанная } \\
\text { система мотивации, } \\
\text { защита прав. }\end{array}$ & $\begin{array}{c}\text { Законодательные } \\
\text { нормы, например, } \\
\text { 40-часовая рабочая } \\
\text { неделя, установлен- } \\
\text { ные минимальные } \\
\text { размеры оплаты, } \\
\text { компенсация свер- } \\
\text { хурочных. }\end{array}$ & $\begin{array}{c}\text { Государство уча- } \\
\text { ствует в формиро- } \\
\text { вании стратегиче- } \\
\text { ских инициатив и } \\
\text { планов. }\end{array}$ & $\begin{array}{c}\text { Ярко выраженный } \\
\text { религиозный кон- } \\
\text { текст всех норм кор- } \\
\text { поративной куль- } \\
\text { туры, соответствие } \\
\text { нормам Шариата }\end{array}$ \\
\hline $\begin{array}{c}\text { Юридическая } \\
\text { ответственность }\end{array}$ & $\begin{array}{c}\text { Нормы поведения } \\
\text { банков законода- } \\
\text { тельно слабо закре- } \\
\text { плены }\end{array}$ & $\begin{array}{c}\text { Правила ведения } \\
\text { бизнеса четко регла- } \\
\text { ментированы и } \\
\text { зафиксированы }\end{array}$ & $\begin{array}{c}\text { Наличие уставов } \\
\text { корпоративного по- } \\
\text { ведения на государ- } \\
\text { ственном уровне, } \\
\text { глубоко проработан- } \\
\text { ная правовая основа }\end{array}$ & $\begin{array}{c}\text { Легитимность суще- } \\
\text { ствования банков } \\
\text { определяется их } \\
\text { соответствиям рели- } \\
\text { гиозным нормам }\end{array}$ \\
\hline $\begin{array}{c}\text { Этическая } \\
\text { ответственность }\end{array}$ & $\begin{array}{c}\text { Поддержка мест- } \\
\text { ных сообществ, на } \\
\text { территории которых } \\
\text { функционирует банк }\end{array}$ & $\begin{array}{l}\text { Степень государ- } \\
\text { ственной защиты, } \\
\text { как и налоговый } \\
\text { уровень, высока }\end{array}$ & $\begin{array}{c}\text { Вектор, направлен- } \\
\text { ный к общему раз- } \\
\text { витию и правиль- } \\
\text { ному ценностному } \\
\text { ориентированию }\end{array}$ & $\begin{array}{c}\text { Продвижение ис- } \\
\text { ламизации, ответ- } \\
\text { ственность за общее } \\
\text { благополучие }\end{array}$ \\
\hline Филантропия & $\begin{array}{c}\text { Финансирование } \\
\text { образования (в боль- } \\
\text { шей степени универ- } \\
\text { ситетов), развития } \\
\text { спорта и культуры }\end{array}$ & $\begin{array}{c}\text { Спонсорская де- } \\
\text { ятельность осу- } \\
\text { ществляется через } \\
\text { финансирование за } \\
\text { счет собранных на- } \\
\text { логов государством } \\
\text { сфер культуры и } \\
\text { образования }\end{array}$ & $\begin{array}{c}\text { Финансирование } \\
\text { образования и куль- } \\
\text { туры, технического } \\
\text { прогресса и защиты } \\
\text { окружающей среды }\end{array}$ & $\begin{array}{c}\text { Продвижение му- } \\
\text { сульманских рели- } \\
\text { гиозных и культур- } \\
\text { ных ценностей }\end{array}$ \\
\hline $\begin{array}{c}\text { Основные } \\
\text { акционеры банков }\end{array}$ & $\begin{array}{c}\text { Акционеры, сотруд- } \\
\text { ники, общество. }\end{array}$ & $\begin{array}{l}\text { Сотрудники, Потре- } \\
\text { бители, Акционеры. }\end{array}$ & $\begin{array}{c}\text { Сотрудники. Акцио- } \\
\text { неры. Сообщества. }\end{array}$ & $\begin{array}{c}\text { Общество, государ- } \\
\text { ство }\end{array}$ \\
\hline $\begin{array}{c}\text { Стимулирование } \\
\text { развития КСО }\end{array}$ & $\begin{array}{c}\text { Банки осуществля- } \\
\text { Ют самостоятельно, } \\
\text { частично сообщества } \\
\text { и НКО }\end{array}$ & $\begin{array}{c}\text { Осуществляется госуд } \\
\text { ществами и, наконе }\end{array}$ & $\begin{array}{l}\text { дарством, затем сооб- } \\
\text { ец, самими банками }\end{array}$ & $\begin{array}{c}\text { Мотивацией явля- } \\
\text { ется необходимость } \\
\text { соответствовать } \\
\text { нормам Корана, } \\
\text { затем уже регулиро- } \\
\text { вание государством } \\
\text { и самими банками }\end{array}$ \\
\hline $\begin{array}{c}\text { Предназначение } \\
\text { НКО }\end{array}$ & $\begin{array}{c}\text { НКО обладают } \\
\text { большой силой, } \\
\text { хорошие отношения } \\
\text { с ними обеспечива- } \\
\text { ют коммерческий } \\
\text { успех, среди них: US } \\
\text { Business for Social } \\
\text { Responsibility }\end{array}$ & $\begin{array}{c}\text { Оказывают серьез- } \\
\text { ное влияние на } \\
\text { банковский бизнес } \\
\text { и обладают автори- } \\
\text { тетом в обществе }\end{array}$ & $\begin{array}{c}\text { Институт НКО не } \\
\text { слишком развит } \\
\text { ввиду отсутствия } \\
\text { необходимости в } \\
\text { нем }\end{array}$ & $\begin{array}{c}\text { Пока НКО разви- } \\
\text { ты недостаточно, } \\
\text { но внедряются, } \\
\text { например, The } \\
\text { Dubai Centre for } \\
\text { Corporate Values, } \\
\text { CSR Association of } \\
\text { Turkey }\end{array}$ \\
\hline $\begin{array}{l}\text { Социальная } \\
\text { отчетность }\end{array}$ & \multicolumn{2}{|c|}{$\begin{array}{c}\text { Досконально проработаны формы и сроки, } \\
\text { закреплены законодательно, понятны всем } \\
\text { основным акционерам }\end{array}$} & $\begin{array}{c}\text { Три направления: } \\
\text { защита прав сотруд- } \\
\text { ников и клиентов, } \\
\text { благотворитель- } \\
\text { ность, защита окру- } \\
\text { жающей среды }\end{array}$ & $\begin{array}{l}\text { Пока на стадии раз- } \\
\text { вития, ввиду доста- } \\
\text { точной закрытости } \\
\text { региона и неразви- } \\
\text { тости многих стран }\end{array}$ \\
\hline
\end{tabular}

Источник. Составлено автором. 


\section{Библиографический список}

1. Адизес И.К. Развитие лидеров. Как понять свой стиль управления и эффективно общаться с носителями иных стилей. Москва. 2014.

2. Борисова Е.И., Кулькова А.Ю. Культура, имена и экономическое развитие // Вопросы экономики. 2016. № 1. С. 85-102.

3. Деминг У.Э. Выход из кризиса. Новая парадигма управления людьми, системами и процессами. Москва. 2014. 417 c.

4. Маслоу А. Мотивация и личность / Пер. с англ. Т. Гутман, Н. Мухина и др. Москва. 2012.

5. Хлевная E.A., Киселёва Т.С. Повышение инициативы сотрудников через развитие эмоционального интеллекта // Менеджмент в России и за рубежом. 2012. № 5. С. 125-133.

6. Шейн Э. Организационная культура и лидерство. 3 е изд. Санкт - Петер бург. 2012. 330 с.

Поступила в редакцию 21.12.2018 